\title{
Regulation of DNA damage responses by mismatch repair
}

\author{
Anatoly Zhitkovich \\ From 16th International Charles Heidelberger Symposium on Cancer Research \\ Coimbra, Portugal. 26-28 September 2010
}

DNA mismatch repair (MMR) is a major genome maintenance system that is responsible for correction of replication errors. Many human cancers exhibit very high rates of spontaneous mutagenesis and a microsatellite instability $(\mathrm{MIN}+)$ phenotype, which are characteristics of inactive MMR. This raises important questions regarding the nature of selection processes leading to the loss of functional MMR during malignant transformation and what it means for the use of specific chemotherapeutic agents. One of the unusual cases of a very high MIN+ incidence ( $>80 \%)$ is lung tumors caused by occupational exposure to carcinogenic hexavalent chromium (Cr-6). Evidence from different cellular models will be presented to demonstrate a critical role of MMR in processing of relatively innocuous DNA phosphate-Cr adducts into highly toxic DNA doublestranded breaks and subsequent activation of stress signaling and apoptosis. MMR-mediated DNA breakage requires a passage of $\mathrm{Cr}$-damaged DNA through $\mathrm{S}$-phase and an unprecedented sequential assembly and activation of both MSH6 and MSH3 branches at S/G2 border. MSH6, a single base mismatch detecting protein, is a sensor of Cr-DNA damage, which subsequently recruits downstream MLH1-PMS2 dimer followed by activation of the MSH3 branch. Inactivation of any of several MMR proteins prevents chromosomal breakage and cytotoxicity by $\mathrm{Cr}-6$. Based on these results, we propose that a chronic exposure to $\mathrm{Cr}-6$ selects for resistant cells with deficient MMR, leading to the outgrowth of populations with a mutator phenotype conferring high transformation potential. Thus, one origin of MIN+ cancers could involve selective pressure imposed by prolonged exposures to specific carcinogens to inactivate

Correspondence: anatoly_zhitkovich@brown.edu Department of Pathology and Laboratory Medicine, Brown University, Providence, RI, USA
MMR. We will also present biochemical and genetic evidence that shed light on the mechanistic basis of differences in sensitivity of MIN+ cancer cells to alkylating chemotherapeutic agents.

Published: 24 September 2010

doi:

Cite this article as: Zhitkovich: Regulation of DNA damage responses by mismatch repair. BMC Proceedings 2010 4(Suppl 2):O5.
Submit your next manuscript to BioMed Central and take full advantage of:

- Convenient online submission

- Thorough peer review

- No space constraints or color figure charges

- Immediate publication on acceptance

- Inclusion in PubMed, CAS, Scopus and Google Scholar

- Research which is freely available for redistribution

Submit your manuscript at www.biomedcentral.com/submit
C Biomed Central 